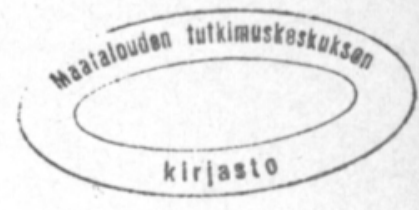

\title{
Effects of a dicamba/MCPA/mecoprop herbicide mixture on the leaves of a barley variety
}

\author{
Helena Savolainen and Kaarina Pihakaski \\ Department of Botany and Laboratory of Electron Microscopy, University of \\ Turku, 20500 Turku 50, Finland
}

\begin{abstract}
Plants of a barley cultivar Pomo were sprayed at 2-node stage with a herbicide mixture, 'Mepro Special', containing dicamba, MCPA and mecoprop, and the plants were grown at two different temperatures, $15^{\circ} \mathrm{C}$ and $23^{\circ} \mathrm{C}$. The effects of the herbicide on the morphology and anatomy were studied by light and electron microscopes and the effects on the chlorophyll content of leaves were studied at various intervals after the spraying.

First sign of damage in the morphology of plants grown both at $23^{\circ} \mathrm{C}$ and $15^{\circ} \mathrm{C}$ were observable $10-12$ days after the spraying but those in the ultrastructure as soon as 1 day after the treatment. The cells of the vascular bundle sheath were most sensitive while the mesophyll cells were unchanged during the total observation period of 12 days at $15^{\circ} \mathrm{C}$. At a higher temperature injuries of various stages were observable also in the mesophyll 6 days after the treatment.

The clearest alterations became visible in the chloroplasts. They swelled to spherical in shape, the intergrana and later also grana lamellae formed vesicles by dilating, later they broke down, and ultimately the plastid envelope disintegrated. The amount of starch and chlorophyll decreased, whereas the number and size of osmiophilic plastoglobuli increased significantly.

The mitochondria swelled, the cristae frequently disappeared and the outer membrane of the envelope distended largely. The nucleus was best capable of resisting the toxic effects of the herbicide. The tonoplast and plasmalemma were broken down a short time before the final disintegration of the cell structures. High temperature obviously reinforced the toxic effects of the herbicide mixture.
\end{abstract}

\section{Introduction}

'Mepro Special' is a commercial Finnish mixture of herbicides dicamba, MCPA and mecoprop. This herbicide mixture has been tested from the beginning of the 1970's by the Agricultural Research Centre at Tikkurila by spraying it on the leaves of several cereals. In the summer 1973 serious injuries were observed in the development of ears of barley and particularly in cv. Pomo. Before the treatment there had been heavy rains and after the treatment the weather had been hot and dry for a long period of time (LALLUKKA, personal communication). The object of this study was to ascertain the changes in the 
anatomy and ultrastructure of leaf, how soon after the spraying they appeared and what sort of changes they were, and whether they were temporary or long-lasting. Differences between the materials grown at $15^{\circ} \mathrm{C}$ and $23^{\circ} \mathrm{C}$ were compared as well.

Several investigations have been carried out at the ultrastructural level on plants treated with various herbicides; in most such investigations the material, seeds or kernels, has been kept in the herbicide solution before sowing (BARTELS and WeIER 1969), or leaves have been kept in the solution (HALlam 1970, BACHELARD and AYLING 1971), or the solution has been injected into the leaves (While and Hemphill 1972). Friesen, Baenziger and Keys (1964) sprayed leaves of barley and wheat with dicamba and made morphological and anatomical but not ultrastructural observations. They found that particularly barley was sensitive to dicamba and that if the plants were treated after a relatively long period from the sowing, the same kind of injuries to the heading occurred as those observed at the Agricultural Research Centre at Tikkurila. 2,4-D causes similar damages in barley as dicamba (FrIESEN and OLson 1953).

\section{Materials and Methods}

Grain of a Finnish barley cv. Pomo were obtained from the Agricultural Research Centre at Tikkurila. Seedlings were grown in soil in cultivating chambers and they were watered every day with destilled water and once a week with Knopp's nutrient solution. Before the treatment all plants were kept in cabins where the light intensity of 9,500 $\mathrm{lx}$ was obtained from fluorescent tubes (Philips white tube, type FLF $40 \mathrm{~W} / 55$ ) while the temperature was $15^{\circ} \mathrm{C}$ for $18 \mathrm{~h}$; the dark period was at $10^{\circ} \mathrm{C}$ for $6 \mathrm{~h}$. These conditions approximately correspond the natural weather conditions at the beginning of a summer in Finland. It was not possible to regulate humidity in the chambers but it ranged between $\mathbf{7 0 - 8 5} \%$.

The herbicide mixture 'Mepro Special' (Kemira Oy) was given by the Research Station at Tikkurila. It contains as active ingredients dicamba $(30 \mathrm{~g} / \mathrm{l})$, MCPA $(261 \mathrm{~g} / \mathrm{l})$ and mecoprop (181 g/l).

The leaves of plants were sprayed by a chromatography sprayer with a solution of $0.4 \mathrm{ml}$ of 'Mepro Special'/100 ml of destilled water $/ \mathrm{m}^{2}$. The spraying was carried out when the plants were at a 2 node-stage, 42 days after the sowing. Then the plants were divided into two groups, one for growing at $15^{\circ} \mathrm{C}$ and another one for growing at $23^{\circ} \mathrm{C}$. For both groups the temperature during the dark period was $10^{\circ} \mathrm{C}$. The untreated plants at corresponding conditions served as controls. The samples for various experiments were taken from the 3 rd and 4 th leaf $1 \mathrm{~h}-24 \mathrm{~h}$ and $3 \mathrm{~d}-12 \mathrm{~d}$ after the treatment.

\section{Microscopy}

The samples were fixed for microscopy in $2.5 \%$ glutaraldehyde made in $0.05 \mathrm{M}$ phosphate buffer, $\mathrm{pH}$ 7.1. The postfixation was carried out in buffered $1 \% \mathrm{OsO}_{4}$ solution. The samples were then dehydrated in ethanol series and embedded in Epon. Sections were cut with glass knives set in the LKB 
Ultrotome III. Semi-thin sections were stained with toluidine blue solution, and thin sections with uranyl acetate and lead citrate and then observed by an AEI EM6B electron microscope.

\section{Chlorophyll determination}

Chlorophyll determinations were carried out according to modified ARnon's method (ARNon 1949). $50 \mathrm{mg}$ of leaves were homogenized in $6 \mathrm{ml}$ of $80 \%$ aceton and sentrifuged for $10 \mathrm{~min}$ at $5,000 \mathrm{x}$. The precipitate was rinsed with $4 \mathrm{ml}$ of aceton and sentrifuged. The supernatants were combined and absorbances were measured at wavelengths $663 \mathrm{~nm}$ and $645 \mathrm{~nm}$. The amount of chlorophyll was estimated by means of ARNON's coefficients.

\section{Results}

When the spraying was commenced the barley plants had 6-7 leaves. After the treatment the morphology of plants grown at $15^{\circ} \mathrm{C}$ and $23^{\circ} \mathrm{C}$ was similar until the leaves of treated plants at $23^{\circ} \mathrm{C}$ turned yellow about $10-12$ days after the spraying. Figure 1 shows barley heads of cv. Pomo grown at the Agricultural Research Centre at Tikkurila in 1974. They are incompletely developed and have many characteristic features caused by 'Mepro Special' in particular growing conditions (cf. LALLUKKA 1976, 1977).

There were no differences observable in the anatomy of leaf at the $1 \mathrm{ig} \mathrm{h} \mathrm{t}$ m i cros c o p e level when the plant materials, untreated and 1 day after the

Fig. 1. Barley heads (cv. Pomo) grown by the Agricultural Research Centre at Tikkurila in 1974, unfully developed after the spraying with 'Mepro Special' herbicide mixture.

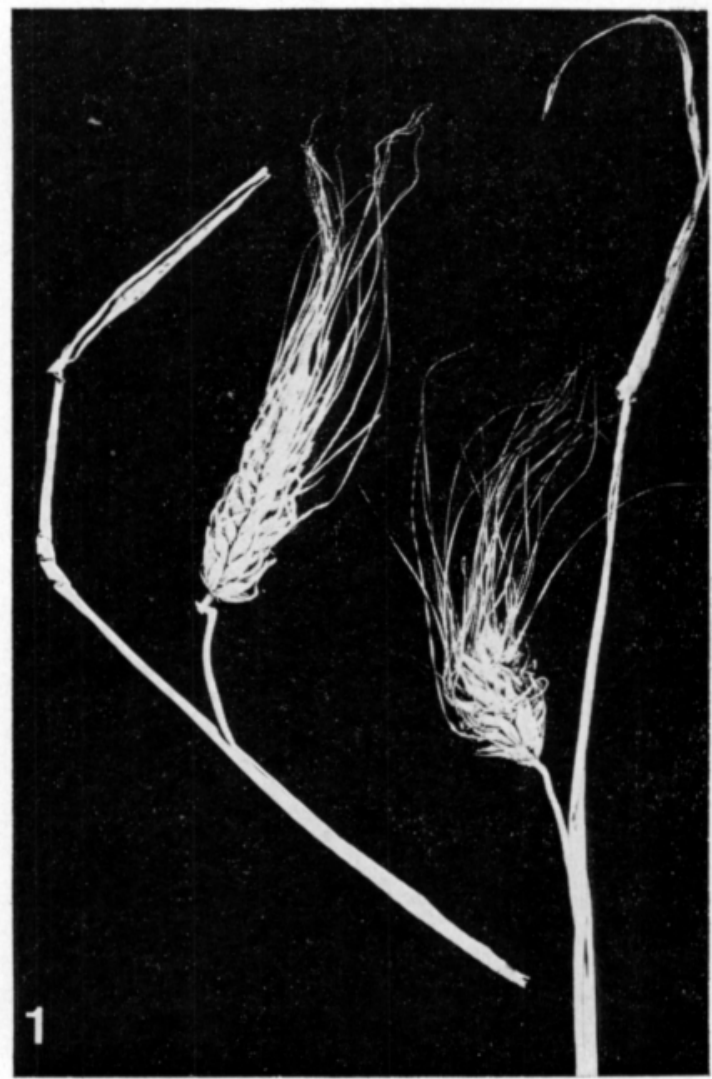


treatment (1-d-treated) grown at $23^{\circ} \mathrm{C}$ or $15^{\circ} \mathrm{C}$, were compared (Figs. 2, 6), but in 6-d-treated leaves at $23^{\circ} \mathrm{C}$ the shape of mesophyll cells was changed (Fig. 4). The change was still greater in 12-d-treated leaves (Figs. 3, 5). The round compact nuclei were well visible and clear alterations in cell membranes were observable. The shape of cells was sharp-cornered and the cells looked empty. The cells of the vascular bundle sheath seemed to be drastically injured (Fig. 3). In samples taken from the plants grown for 12 days at $23^{\circ} \mathrm{C}$ there were cells which differed from the surrounding cells (Fig. 7). They were stained weakly with toluidine blue, chloroplasts had different localization in cells and they seemed to have more starch than those of normal cells.

Figure 8 shows a typical mesophyll cell of a control plant, grown at $15^{\circ} \mathrm{C}$, at the electron microscope level: the nucleus at the centre of the cell and many chloroplasts with small starch grains surrounding it and a central vacuole (cf. also Fig. 10). The shape of chloroplasts is oval and regularly formed grana are well observable in Fig. 12. Occasionally granular electron dense areas are visible at the end of control chloroplasts (Fig. 12 arrows). Mitochondria, from spherical to rod-shaped, and microbodies are often in the close vicinity of chloroplasts (Fig. 9). Dictyosomes comprising of 4 to 5 cisternae, clusters of ribosomes and endoplasmic reticulum (ER) cisternae were detected in the cytoplasm, as well.

The ultrastructure of the mesophyll cells of 6-d-treated plants did not differ from the control ones. Even the 12-d-treated samples showed only somewhat slight alterations apparently caused by the herbicides; various sorts of vesicles were more abundant in the cytoplasm and appeared occasionally as inclusions in the chloroplasts and mitochondria. Myelinlike formations were also more frequently visible than in the untreated samples. Occasionally the contours of tonoplast and plasmalemma revealed changes. One third of the plastids were without starch (Fig. 17).

Injured cells in the vascular bundle sheath could be observed 1 day after the treatment in the plants grown at $15^{\circ} \mathrm{C}$. The chloroplasts were damaged; the ends of thylakoids were swelled saccate, and the intergrana and grana thylakoids at many sites were broken (Figs. 10, 11). The structure of mitochondria was altered, as well; most often the cristae and the inner membrane of the envelope had disappeared. ER cisternae were broken and formed small vesicles in the cytoplasm. The tonoplast was frequently ruptured.

The herbicide treatment seemed to cause a vigorous accumulation of starch in the chloroplasts, although only a temporary one. The starch amount increased manifold in samples at $15^{\circ} \mathrm{C}$ taken 1 to 3 hours after the treatment (Fig. 17) and enormous starch grains were almost bulging out of plastids (Fig. 13). The starch content, however, began to decrease very rapidly, and in the 1-d-treated samples there were no such chloroplasts visible in which the area of starch covered half or more of the total area in the sectioned chloroplasts.

The untreated plants grown for 1 to 6 days at $23^{\circ} \mathrm{C}$ or $15^{\circ} \mathrm{C}$ resembled each other in regard to subcellular morphology, but in the material grown at $23^{\circ} \mathrm{C}$ for 12 days there was a portion of cells with clear ageing features (cf. Fig. 7). Large lipid droplets occurred in the cytoplasm and the amount of starch was obviously decreased. Many kinds of vesicles, e.g. multivesicular 


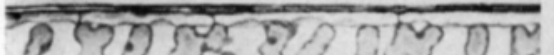
obo sorrome mos \% 3 कर मे है के

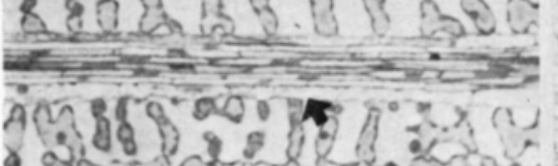

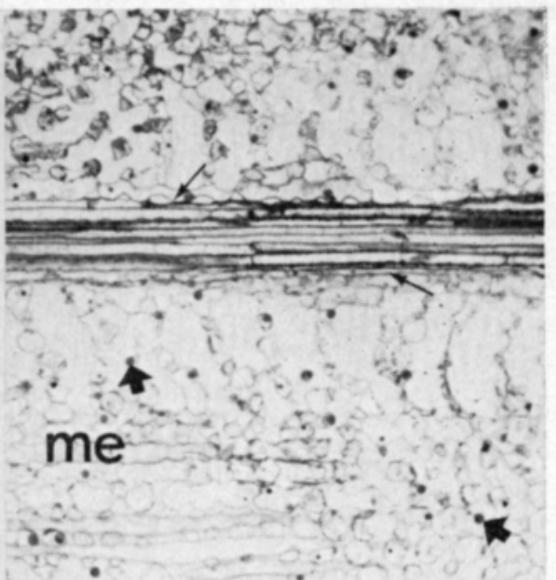

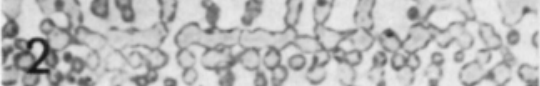

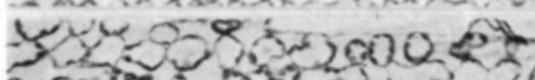

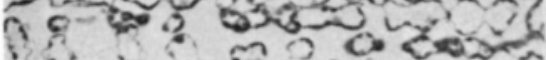

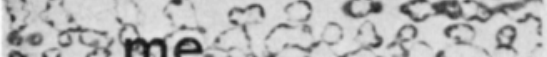
\%००

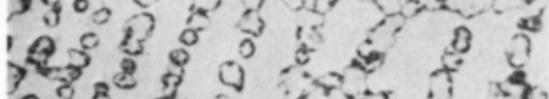

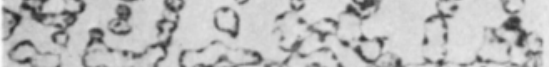

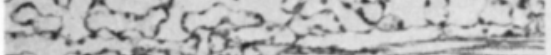

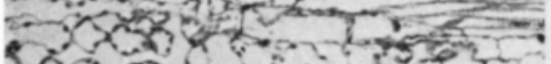

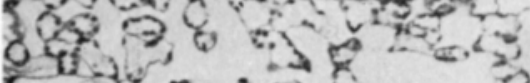
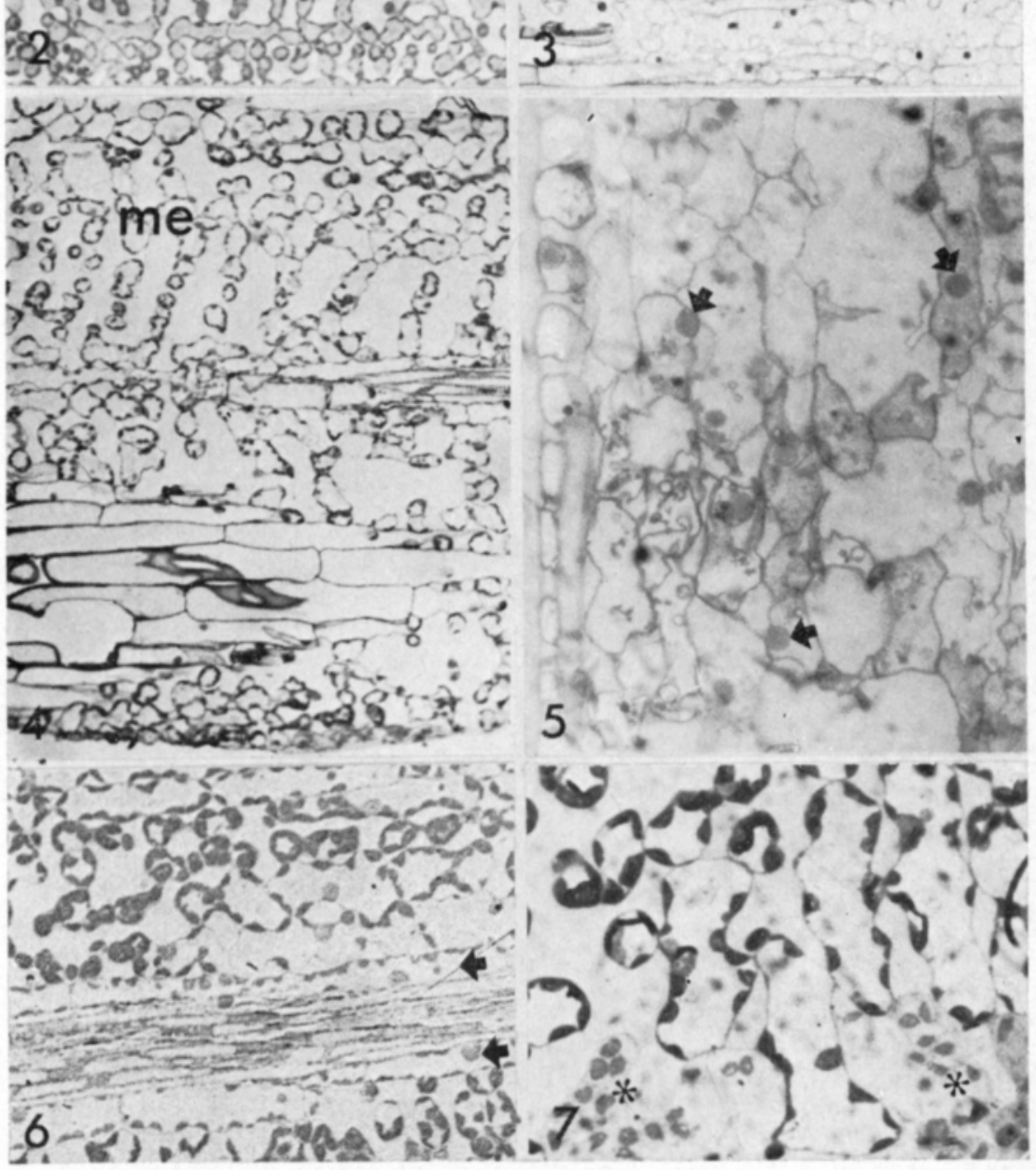

Fig. 2. A longitudinal section of a control leaf grown at $23^{\circ} \mathrm{C}$ for 1 day. The mesophyll cells (me) are regular in shape; also the vascular bundle sheath comprises of normal cells (arrows). X 160 .

Fig. 3. A longitudinal section of a leaf grown at $23^{\circ} \mathrm{C}$ for 12 days after the treatment. The cells are sharp-cornered, the nuclei are round in shape and well stained with toluidine blue (heavy arrows). The cells of vascular bundle sheath are seriously injured (small arrows). $\mathrm{X} 160$.

Fig. 4. The material as in Fig. 3 but 6 days after the treatment. The mesophyll cells are injured. $\mathrm{X} 160$.

Fig. 5. A portion of mesophyll from a leaf grown at $23^{\circ} \mathrm{C}$ for 12 days after the treatment. The cells are empty of normal cytoplasm. The nuclei are well visible (arrows). $\mathrm{X} 380$. Fig. 6. Tangentially sectioned mesophyll and phloem of a control leaf tissue, grown at $15^{\circ} \mathrm{C}$. The arrows show the cells of the vascular bundle sheath. X 290 .

Fig. 7. Mesophyll of a control leaf grown at $23^{\circ} \mathrm{C}$ for 12 days. Most of the cells are normal but a portion of them are injured by the long-lasting high temperature (asterisk). X 375 . 

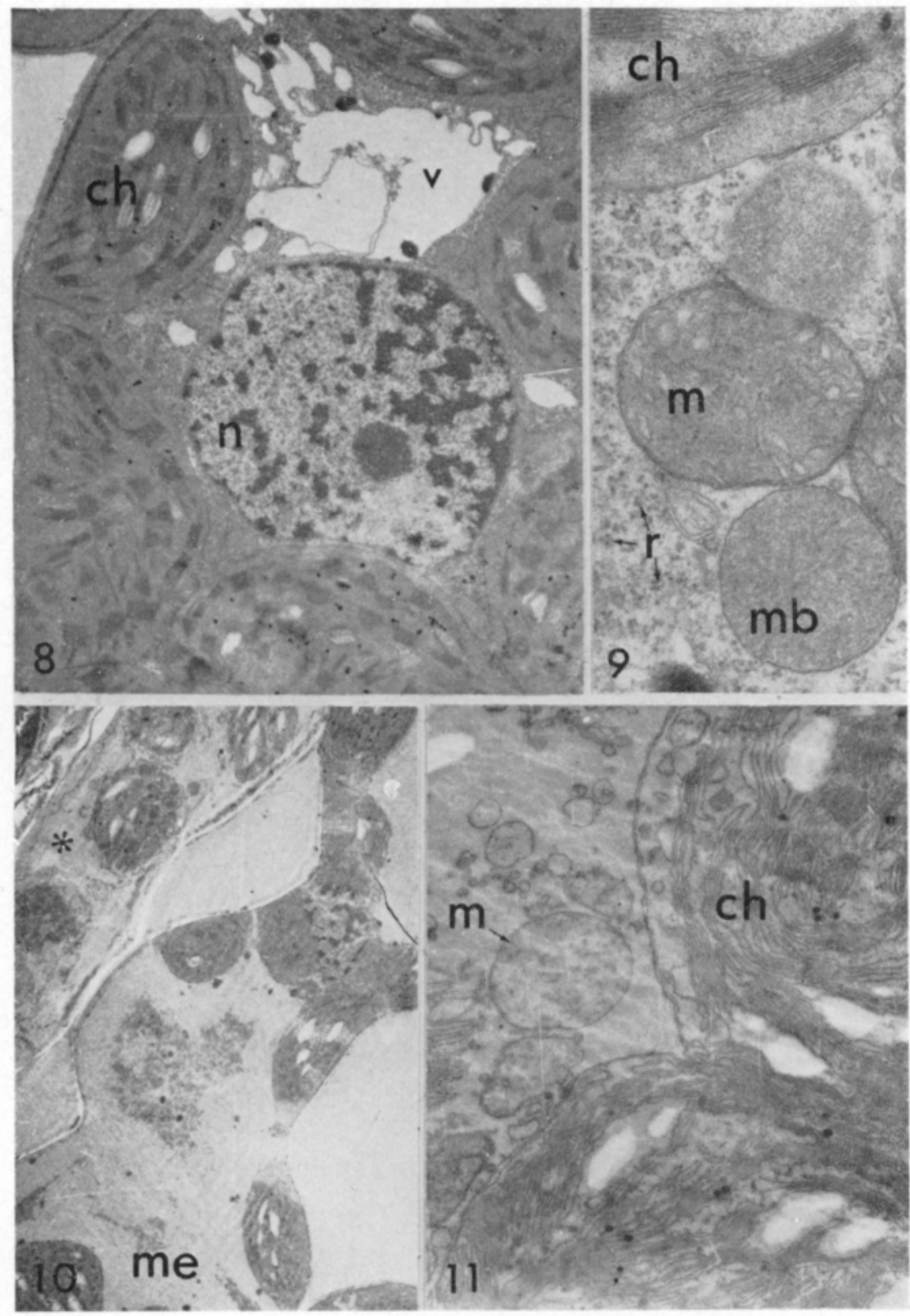

Fig, 8. A control mesophyll cell of a leaf grown at $15^{\circ} \mathrm{C}$ with a round-shaped nucleus (n) and vacuole (v) at the centre of the cell and chloroplasts (ch) surrounding it. $\mathbf{X} 6300$. Fig. 9. Mitochondria $(\mathrm{m})$, a microbody $(\mathrm{mb})$, a part of a chloroplast (ch) and ribsomes ( $\mathrm{r}$ ) in a control cell $\left(15^{\circ} \mathrm{C}\right)$. X 25500 .

Fig. 10, An undamnaged mesophyll cell and a damaged cell of a vascular bundle sheath (asterisk), $15^{\circ} \mathrm{C} 1$ day after the treatment. X 2580 .

Fig. 11. Damaged chloroplasts and mitochondria in an injured cell of a vascular bundle sheath, $15^{\circ} \mathrm{C} 1$ day after the treatment. $\mathrm{X} 12750$. 


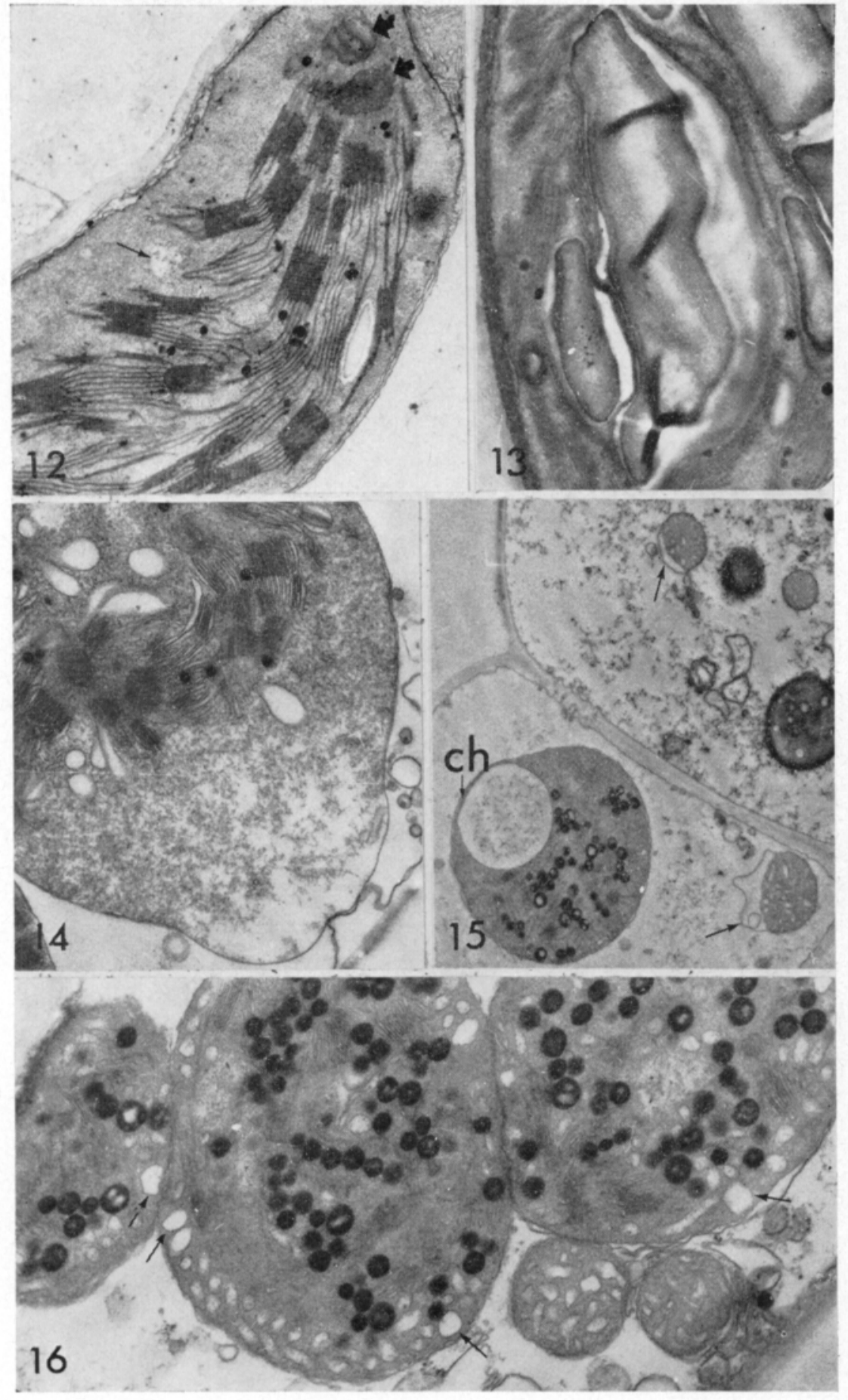

Fig. 12. A chloroplast of a control cell $\left(15^{\circ} \mathrm{C}\right)$, in which only a small starch grain is visible. Heavy arrows show electron opaque areas without lamellae at one end of the plastid. Also plastid DNA is visible (small arrow). $\mathrm{X} 17000$.

Fig. 13. A chloroplast 3 hours after the treatment $\left(15^{\circ} \mathrm{C}\right)$ contains starch abundantly. $\mathrm{X} 17000$.

Fig. 14. A damaged chloroplast, $23^{\circ} \mathrm{C} 6$ days after the treatment. The inner membrane of the envelope is broken. $\mathrm{X} 11250$.

Fig. 15. Injured leaf cells, $23^{\circ} \mathrm{C} 12$ days after the treatment. Inclusion vesicle in a chloroplast (ch), the outer membranes of mitochondrial envelopes distended (arrows). X 8500 .

Fig, 16. Strongly changed chloroplasts, $23^{\circ} \mathrm{C} 12$ days after the treatment. The tylakoids have enlarged to small vesicles (small arrows). The size and number of osmiophilic plastoglobuli have increased. $\mathrm{X} 14600$. 
bodies, were visible in abundance. The shape of chloroplasts had altered from oval to spherical. The inner membrane of the chloroplast envelope was frequently broken or disappeared but osmiophilic plastoglobuli were of normal size and number. The disorganization of the granal arrangement at various stages was visible in a large portion of chloroplasts. The ultrastructure of mitochondria may also be grossly altered by the long growing at the high temperature.

Changes in the ultrastructure of the mesophyll cells of 1-d-treated plants grown at $23^{\circ} \mathrm{C}$ were similar to those observed in 12-d-treated plants grown at $15^{\circ} \mathrm{C}$. The decrease in the amount of starch was significant after one day. The same features were strengthened in the 6-d-treated material (Fig. 14). Almost a half of the chloroplasts were without strach (Fig. 18). The amount of plastoglobuli had increased but their size was normal. The plastid envelope could be inflated and occasionally the inner membrane was entirely disorganized; the grana, however, were still discernible. The leaf cells of 12-d-treated plants grown at $23^{\circ} \mathrm{C}$ had altered somewhat drastically, as it was obvious also in the light micrographs (cf. Figs. 3, 5, 15). Occasionally the large central vacuole was still undamaged and the cytoplasm seemed to be only slightly changed, but most often the tonoplast was ruptured and the content of the cell was a disorganized mixture of various kinds of vesicles and membrane formations. The compartments of chloroplasts had swollen forming small vesicles in the stroma. The plastoglobuli were increased both in size and number (Fig. 16). Sometimes large inclusions, possibly invaginations of cytoplasm, were engulfed in the chloroplasts (Fig. 15). Starch was observable only occasionally (cf. Fig. 18). The most striking feature in the structure of mitochondria was the dilated outer membrane of the envelope (Fig. 15).

Figure 19 shows the chlorophyll content, total chlorophyll and chlorophyll $\mathrm{a}$ and $\mathrm{b}$, of barley leaves grown at $23^{\circ} \mathrm{C}$ determined at various intervals after the treatment. All the way through the chloropyll content decreases both in
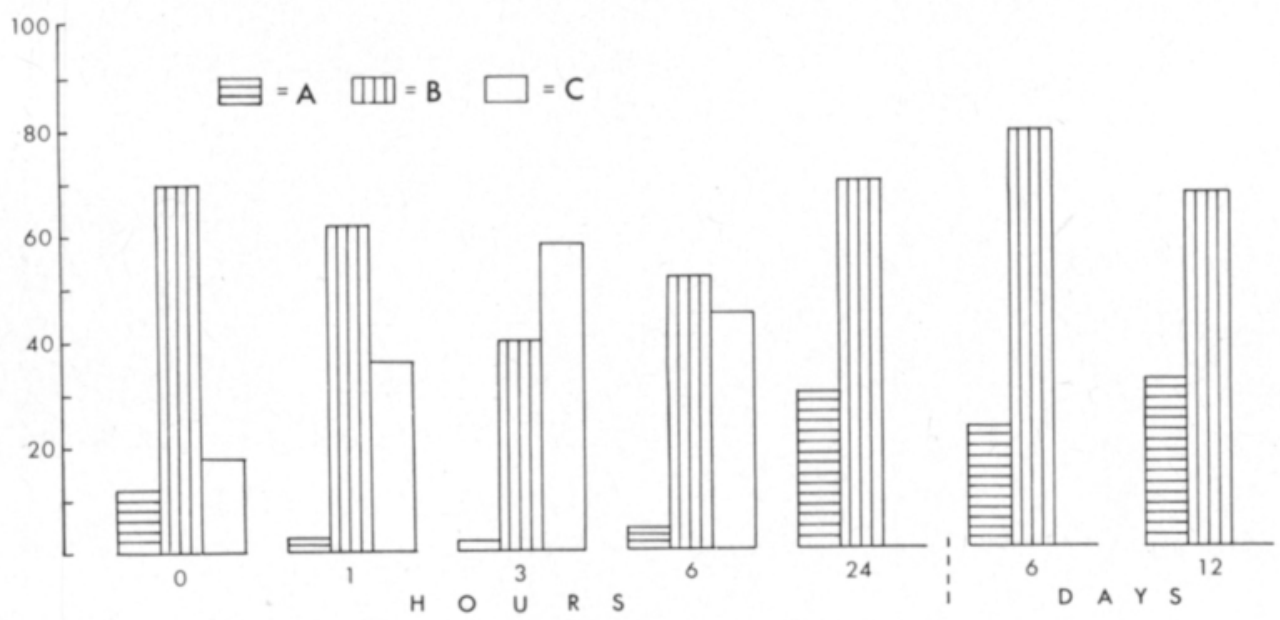

Fig. 17. The amount of starch in the sectioned chloroplasts of barley observed at different intervals after the spraying $\left(15^{\circ} \mathrm{C}+10^{\circ} \mathrm{C}\right)$. The estimated area covered by the starch grains from the total area of sectioned chloroplasts expressed as precent. 

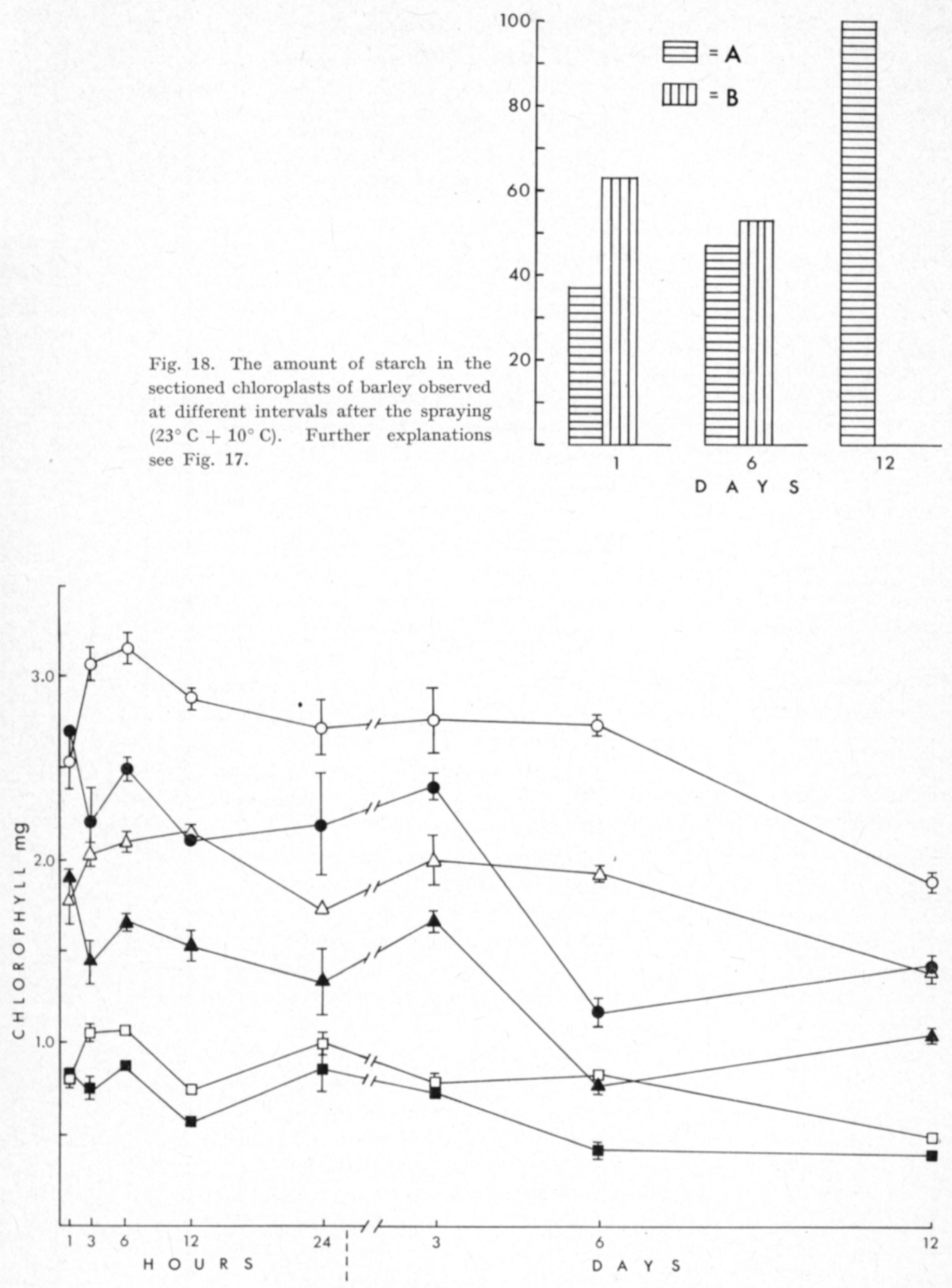

Fig. 19. The chlorophyll content of barley leaves (mg per $\mathrm{g}$ of fresh weight) determined at various intervals (hours or days) from control and treated plants $\left(23^{\circ} \mathrm{C}+10^{\circ} \mathrm{C}\right)$. 
the control and in the treated plants. Further examining of the curves shows a rapid decrease in the 3-d-treated material particularly in chlorophyll a, and in consequence, also in the total chlorophyll. The decrease of the total chlorophyll between 3 and 6 days after spraying is $1.2 \mathrm{mg}$ per $\mathrm{g}$ of fresh weight.

\section{Discussion}

The optimum temperature for barley is much below $20^{\circ} \mathrm{C}$ (ÄYRÄvÄINEN and PAatela 1974), which makes barley more capable of resisting the effects of herbicides at lower temperatures than at higher ones, and therefore it also needs then longer to become injured. In addition, the present observations suggest both at light and electron microscope level that the cells of vascular bundle sheath are very strongly altered by the herbicides also at low temperature. These alterations, the rapid increase of starch and damages in cell organelles, e.g. in chloroplasts and mitochondria, take place very soon after the treatment. This is obviously due to the known fact that the transport of dicamba and auxin-herbicides takes place along the phloem (AAmisepp et al. 1970, Ashton and CRAFTS 1973). Therefore also the mesophyll cells may structurally be entirely undamaged a short time after the treatment but in a few days the herbicides are transported also to the parenchymatous cells of the mesophyll. In its main features the disruption of cell organelles caused by 'Mepro Special', resembles the normal senescence (cf. Butler and Simon 1971, Anderson and Thomson 1973, Harris and ArnotT 1973). The ageing started to alter the ultrastructure of barley mesophyll cells after growing for 6 days at high temperature. Hallam (1970) and White and Hemphill (1972) have found similar membrane formations in leaf cells with 2,4-D as the ones 'Mepro Special' has caused in the present study. Also the structural changes in the mitochondria of 12-d-treated samples of the present study were similar to those in soybean hypocotyls altered by 2,4-D (BAxter and HAnson 1968). The 2,4-D treatment increased the functional activity of mitochondria simultaneously. 'Mepro Special' contains MCPA and mecoprop which are synthetic auxin-herbicides as is also 2,4-D, therefore it is also expected that the effects of 'Mepro Special' are very similar to those of 2,4-D. DERSCheID (1952) has described similar incomplete development of barley head with 2,4-D as LALLUKKA $(1976,1977)$ has reported on the use of dicamba/MCPA/mecoprop herbicide mixture.

The alterations in the shape of chloroplasts from oval to spherical are explained by ANDERSON and Schalling (1970) by permeability changes in the plastid envelope. Another ultrastructural change in chloroplasts observed in the present study was the swelling of compartments of grana; the frets or a part of them were distroyed leading to the disorganization of the grana arrangement. Similar alterations have been caused by ultrasound and osmotic shock treatments as well as with atrazine (Ashton et al. 1963, WEIER et al. 1965), with pyrazon (Ashton and CRAFTs 1973), and with 2,4-D (White and Hemphill 1972). The changes in the chloroplast thylakoids lead ultimately to the bursting of the plastid envelope releasing the plastid stroma. This gives rise to a chloroplast "skeleton" consisting of the bare internal lamellar system and the plastoglobuli. The physiological mode of action of 'Mepro Special' 
differs from that of atrazine and pyrazon which both inhibit photosynthesis, but yet the ultrastructural changes caused by all these herbicides have similar appearance.

The number and size of osmiophilic plastoglobuli depends on the age and physiological conditions (Lichtenthaler 1968). Since the plastoglobuli are known to be lipid storage bodies intimately associated with the lipid content of chloroplast membranes, the increase in globule size is apparently due to an increase of free lipids made available by the degradation of chloroplast membranes (White and Hemphill 1972, Anderson and Thomson 1973, Harris and ArnotT 1973). 'Mepro Special' decisively disturbs the carbohydrate metabolism, which appears soon after the treatment as accumulation of starch and later as decreasing and disappearing of starch. This is apparently due to the prevention of photosynthesis (Ashton and CRAFTs 1973). Since grana lamellae and chlorophylls decompose and photosynthesis is prevented the cell soon uses up the storage starch for its energy (CRAN and Possingham 1974). The ultrastructural breakdown of cells is based on an alteration of the sturctural integrity of cell membranes. This might be caused by an interaction of the auxin-herbicide molecule with the protein components of the membranes.

On the basis of the observations presented above the following general conclusions can be drawn:

Although cv. Pomo was grown in optimal temperature after the spraying and although the morphology appeared to be normal, distinct injuries were observed in the ultrastructure of the cells of vascular bundle sheath. Therefore, electron microscopy can be utilized when predicting the degree of damage.

Acknowledgements. - The authors wish to express their deep gratitude to Mr. Risto Lallukka, M. Agric. Sci. Agricultural Research Centre, Department of Plant Husbandry, Vantaa, for his inspiring attitude to this work, and to Mrs. Ulla-Maija Suoranta and Miss Katri Rouvali for their skillful technical assistance. This work was financially supported by the Jenny and Antti Wihuri Foundation.

\section{REFERENCES}

Aamisepp, A., Bärring, U., Ebbersten, S., Erne, K., Granström, B., Lundin, J., Svensson, A. \& ÅBERG, E. 1970. Översiktrörande moderna kemiska växtbekämpningsmedels civila och militärä användning och effekter. FOA 1 Rapp. A 1513-31. Sept. 1970. Avd. 1. 158 p.

Anderson, J. L. \& Schaelling, J. P. 1970. Effects of pyrazon on bean chloroplast ultrastructure. Weed Sci. 18: 455.

- - \& Tномpson, W. W. 1973. Effects of herbicides on the ultrastructure of plant cell. Res. Rev. 47: 167-185.

Arnon, D. J. 1949. Copper enzymes in isolated chloroplasts. Polyphenol-oxidase in Beta vulgaris. Plant Physiol. 24: 1-15.

Ashton, F. M. \& Crafts, A. S. 1973. Mode of action of herbicides. - Wiley-Interscience Publ. 504 p. New York \& London.

- - , Gifford, E. M. Jr. \& Bisalbutra, T. 1963. Structural changes in Phaseolus vulgaris induced by atrazine. II. Effects on fine structure of chloroplasts. Bot. Gaz. 124: 336343.

Bachelard, D. P. \& Ayling, R. D. 1971. The effects of picloram and 2,4-D on plant cell membranes. Weed Res. 11: $31-36$. 
Bartels, P. C. \& Weier, T. E. 1969. The effect of 3-amino-1,2,4-triazole on the ultrastructure of plastids of Triticum vulgare seedlings. Am. J. Bot. 56: 1-7.

Baxter, R. \& Hanson, J. B. 1968. The effect of 2,4-dichlorophenoxyacetic acid upon the metabolism and composition of soybean hypocotyl mitochondria. Planta (Berl.) 82: $246-260$.

Butler, R. D. \& Simon, E. W. 1971. Ultrastructural aspects of senescence in plants. Adv. Gerontol. Res. 3: 72.

Cran, D. G. \& Possingham, J. V. 1974. The effect of cell age on chloroplast structure and chlorophyll in cultured spinach leaf discs. Protoplasma 79: 197-213.

Derscheid, L. A. 1952. Physiological and morphological responses of barley to 2,4-dichlorophenoxyacetic acid (2,4-D). Plant Physiol. 27: 121-134.

Friesen, G. \& Olson, P. J. 1953. The effect of 2,4-D on the development processes in barley and oats. Can. J. Agr. Sci. 33: 315-329.

- - , Baenziger, H. \& Keys, C. H. 1964. Morphological and cytological effects of dicamba on wheat and barley. Can. J. Plant Sci. 44: 288-294.

Gahan, P. B. 1968. Lysosomes. In Plant Cell Organelles. (Ed. J. B. Pridham) 261 p. Acad. Press, London \& New York.

Hallam, N. D. 1970. The effect of 2,4-dichlorophenoxyacetic acid and related compounds on the fine structure of the primary leaves of Phaseolus vulgaris. J. Exp. Bot. 21: 10311038.

Harris, J. B. \& Arnotr, H. J. 1973. Effects of senescence on chloroplasts of the tobacco leaf. Tissue \& Cell 5: 527-544.

LALluKKa, R. 1976. Effects of a dicamba/MCPA/mecoprop mixture, on eight spring barley cultivars. Proc. 1976 Brit. Crop Protect. Conf. - Weeds, p. 143-150.

- - 1977. Dicamba injuries to barley. Weeds and Weed Control. 18th Swed. Weed Conf., Uppsala 27-28 Jan. 1977.

Lichtenthaler, H. K. 1968. Plastoglobuli and the fine structure of plastids. Endeavour 27: $144-149$.

Sawamura, S. 1964. Cytological studies on the effect of herbicides on plant cells in vivo. I. Hormonic herbicides. Cytologia 29: 86-102.

Weier, T. E., Stocking, C. R., Bracker, C. E. \& Risley, E. B. 1965. The structural relationships of the internal membrane systems of in situ and isolated chloroplasts of Hordeum vulgare. Am. J. Bot. 52: 339-352.

White, J. A. \& Hemphill, D. D. 1972. An ultrastructural study of the effects of 2,4-D on tobacco leaves. Weed Sci.20: $478-481$.

ÄYrävärnen, K. \& PAAtela, J. 1974. The effect of temperature and growth density on the development and yield of two and multi-rowed barley varieties. J. Scient. Agric. Soc. Finl. 46: 11-31.

Ms received March 23, 1978

\title{
SELOSTUS
}

\section{Dikamba/MCPA/mekoproppi-herbisidiseoksen vaikutukset ohran lehteen}

\author{
Helena Savolainen ja KaArina Prhakaski \\ Turun yliopiston biologian laitos, kasvitieteen ja elektronimikroskopian osastot, Turku
}

Ohran Pomo-lajikkeen 2-solmuasteella olevia yksilöitä ruiskutettiin kotimaisella 'Mepro Special'-rikkakasvihävitteellä, joka sisältää dikambaa, MCPA:ta ja mekoproppia. Käsiteltyjä ja kontrollikasveja kasvatettiin tämän jälkeen $15^{\circ} \mathrm{C}$ tai $23^{\circ} \mathrm{C}$ :ssa pitkänpäivän olosuhteissa pimeäjakson lämpötilan ollessa $10^{\circ} \mathrm{C}$. Lehdistä otettiin näytteitä valo- ja elektronimikroskopiaa varten sekä klorofyllimäärityksiin eri aikoina 12 päivän kuluessa. 
Kasvien morfologiassa nähtiin ensimmäiset merkit herbisidin haittavaikutuksista lehtien kellastumisena molemmissa lämpōtiloissa vasta 10-12 päivää ruiskuttamisen jälkeen. Hienorakenteessa sensijaan näkyi muutoksia johtojännetupen soluissa selvästi jo 1 päivän kuluttua. Mesofyllin solut pysyivät lähes muuttumattomina $15^{\circ} \mathrm{C}$ :ssa koko havaintojentekoajan, mutta $23^{\circ} \mathrm{C}$ :ssa vaurioita alkoi esiintyä selvästi 6 päivän kuluttua. Organelleista herkimpiä olivat kloroplastit, joiden muoto aluksi muuttui pyöreäksi. Ensin paisuivat intergranatylakoidit ja sitten granatylakoidit muodostaen pieniä rakkuloita. Osmiofiilisten plastoglobuloitten määrä ja koko kasvoi huomattavasti. Myöhempiä vaurioitumisen merkkejä olivat lamellien ja kloroplastikelmun sekä tonoplastin rikkoontuminen. Myös mitokondriot turposivat, ja kristat saattoivat hävitä kokonaan. Usein kelmun ulompi kalvo irtosi sisäkalvosta venyen pussimaisesti. Plasmalemman rikkoonnuttua solun kaikki rakenteet hajosivat.

Tärkkelyksen määrässä todettiin huomattava nousu $15^{\circ} \mathrm{C}$ :ssa kasvaneissa kasveissa 3 t käsittelyn jälkeen, mutta 1 pv käsittelystä sekä tärkkelyksen että klorofyllin määrä alkoivat laskea. Korkea lämpötila lisäsi selvästi myrkkyvaikutuksia, mikä näkyi rakenteiden muutoksinakin. Riittävästä kastelusta huolimatta voitiin todeta, että 6 pv $23^{\circ} \mathrm{C}: s s a$ kasvaneissa kontrollikasveissa alkoi esiintyä yleisiä solun vanhenemiseen liittyviä muutoksia, osoittaen Pomolajikkeen kärsivän aineenvaihdunnan eri tasoilla. 